\title{
IMPLEMENTASI NILAI NILAI AL-QUR'AN DALAM PENDIDIKAN KARAKTER USIA REMAJA
}

\author{
Nur Illahi \\ ${ }^{1}$ Nurillahi0876@gmail.com
}

\begin{abstract}
Abstracs
Al-Qur'an values in adolescent character education was one part that must be considered.Al-Qur'an was one of the means of character development.Therefore,the development of adolescent character education in accordance with the Qur'an is absolutely done.There were so many values in the Qur'an character values that can be taken to carry out Islamic education, because the values were certain to be relevant to the objective of Islamic education.The implementation of adolescent character education in

the values of the Qur'an was a method of analytical research inlearning Islamic education.Data collection techniques in this research was literature study.In the Qur'an there were values contained in adolescent character education including adherence, responsibility, compassion, peace, fairness and social care the values of taqwa contained in religious character were complex character in education some method that can be used among others, targhib

methods, stories, habituation, commands, prohibition, dialogue (debate) and qudwah.The purpose of this study was to determine the values of the Qur'an in the character education of adolescent in the learning of Islamic education.
\end{abstract}

Key word : Al Qur an Values,Adolescent character education,Islamic religious education.

\section{Abstrak}

Nilai nilai Alqur'an dalam pendidkan karakter usia remaja merupakan salah satu bagian yang harus diperhatikan.Al-Qur'an merupakan salah satu sarana pengembangan karakter.Oleh karena itu penembangan pendidikan karakter usia remaja yang sesuai dengan Al-Qur'an mutlak di lakukan.Ada begitu banyak dalam Al-Qur'an nilai nilai karakter yang dapat diambil untuk melaksanakan pendidikan islam,karena nilai nilai tersebut sudah pasti akan relevant dan sejalan dengan tujuan pendidikan islam.Implementasi pendidikan karakter usia remaja dalam nilai nilai Al-Qur'an merupakan metode penelitian analisis dalam pembelajaran pendidikan agama islam.Tehnik pengumpulan data yang di gunakan dalam penelitian ini adalah study kepustakaan.Dalam Al-Qur'an terdapat nilai nilai yang terkandung dalam pendidikan karakter usia remaja diantaranya adalah : ketaqwaan,tanggung jawab,kasih sayang,cinta

\footnotetext{
${ }^{1}$ Dosen Tetap Prodi PAI STAI Asy-Syukriyyah Tangerang
} 
damai,adil dan kepedulian sosial.Nilai taqwa yang terdapat pada karakter religius merupakan karakter komplek dalam pendidikan karakter usia remaja.Beberapa metode yang dapat di pakai antara lain metode targhib,kisah,pembiasaan,perintah, larangan,dialog(debat)dan qudwah.

\section{Pendahuluan}

Al-Qur'an adalah kitab suci umat Islam dan memiliki konsep yang paripurna sehingga bisa memberikan solusi terbaik dalam kehidupan manusia. Al-Qur'an telah berhasil mendidik nabi muhammad dan para sahabatnya menjadikan mereka generasi terbaik. Serta mampu membangun peradaban baru yang menggantikan peradaban lama (arab sebelum islam) yang penuh dengan kejahilan,kemusrikan dan ketidakadilan. Kitab alQur'an yang merupakan sumber pengetahuan, sumber inspirasi dan sumber kreativitas untuk memecahkan berbagai persoalan manusia telah terbukti secara ilmiah dan memberikan kontribusi besar bagi ilmu pengetahuan dunia.Sebagai kallam Allah yang diwahyukan kepada nabi muhamad SAW, al-Qur'an menjadi sumber pendidikan Islam pertama dan utama.

Sejalan dengan itu nilai nilai al-Qur'an menjadi barometer dunia islam sebagai penggerak roda ilmu pengetahuan di berbagai bidang.Berbagai ilmu pengetahuan sudah banyak membuktikan dari aspek kehidupan bahwa al-Qur'an telah mampu membawa manusia dari kehidupan yang tidak baik menuju kehidupan yang lebih baik. Dalam hal ini al-Qur'an telah banyak memberikan warna diantaranya inspirasi dalam kehidupan bermasyarakat dan bernegara.Kendati demikian tidak sedikit banyak dari kalangan umat islam sendiri tidak mau menjalankan nilai nilai al-Qur'an berupa menjalankan aturan aturan yang telah di tetapkan dikarenakan minimnya pengetahuan tentang al-Qur'an itu sendiri dan kesombongan akan memiliki ilmu pengetahuan yang lain yg didasari oleh logika semata.

Semua unsur dalam kehidupan di alam raya ini tidak akan terlepas dari dua landasan tersebut. Jika kedua landasan itu ditinggalkan maka tidak menutup kemungkinan semua kehidupan di dunia ini akan mengalami kerusakan di berbagai sektor. Mulai dari 


\section{Jurnal Asy-Syukriyyah}

dekadensi moral, kerusakan alam dan hancurnya keseimbangan kondisi kehidupan manusia secara natural. Merujuk pada uraian di atas, maka sebagai pedoman hidup, al-Qur'an dan hadis mesti dijadikan imam atau ikutan dalam kehidupan sehari-hari dimana kedua sumber ini dipatuhi, diacu dan dilaksanakan perintah-perintahnya serta meninggalkan laranganlarangannya. Tulisan ini akan mengupas tentang seberapa pentingkah pendidikan karakter, dan bukti-bukti tentang jawaban bahwa apakah al-Qur'an bisa menjadi dasar dari pembentukan karakter pada usia remaja ?

\section{Tinjauan Pustaka}

Lafadz al-Qur'an dalam bahasa Arab diambil dari kata Qara'a(قرأ() seperti lafadzAl-ghufran yang diambil dari kataghafara(غفر). Dikatakan qira'a, yaqra'u, qira'atan dan qur'anan (قرأ- يقرؤ- قرأة-). Diantaranya adalah firman Allah SWT:

Dan dalam Kamus Ilmu Ushul Fikih, dikatakan bahwa lafadz al-Qur'an merupakan bentuk mashdar dari qara'a(قرأ) yang sepadan dengan kata fu'lan. Ada dua pengertian alQur'an dalam bahasa Arab, yairu qur'an (قرآن) berarti bacaan, dan apa yang tertulis padanya, maqru(مقرو'), isim fa'il (subjek)dari qara'a (al-Qiyamah (75) ayat 17-18). ${ }^{2}$

Secara terminologi, ada beberapa definisi dari pengertian al-Qur'an adalah wahyu atau firman Allah swt yang diturunkan kepada Rasulullah saw melalui perantaraan malaikat Jibril dengan menggunakan bahasa Arab, untuk pedoman bagi umat manusia, merupakan mukjizat Nabi Muhammad saw yang terbesar, dinukilkan kepada kita secara mutawatir dan dinilai ibadah bagi yang membacanya.

Abdul Wahhab Khallaf mengemukakan tentang kehujjahan al-Qur'an sebagai berikut: "Bukti bahwa al-Qur'an menjadi hujjah atas manusia yang hukum-hukumnya merupakan aturan-aturan yang wajib bagi manusia untuk mengikutinya, ialah karena alQur'an datang dari Allah swt. dan dibawa kepada manusia dengan jalan yang pasti yang tidak diragukan kebenarannya. Sedang bukti bahwa al-Qur'an itu datang dari Allah swt

${ }^{2}$ Drs. Totok Jumantoro, M.A., Drs. Samsul Munir Amin, M.Ag., Kamus Ilmu Ushul Fikih, Jakarta: Penerbit Amzah 2009, hlm. 6 


\section{Jurnal Asy-Syukriyyah}

adalah bahwa al-Qur'an membuat orang-orang tidak mampu membuat atau mendatangkan sesuatu seperti al-Qur'an (kemukjizatan al-Qur'an). ${ }^{3}$ ",

Al-Qur'an telah lengkap dalam melakukan tantangan, dan terdapat pula motivasi bagi orang yang menantangnya untuk melawan, dan tidak suatu penghalang bagi mereka. Kendati demikian, mereka tidak sanggup melawannya dan juga mendatangkan yang semisal al-Qur'an ${ }^{4}$.

Menurut Muhammad Khuderi Bek dalam bukunya "Tarikh Tasyri' al-Islami", ada tiga prinsip yang melandasi hukum dalam al-Qur'an; ${ }^{5}$

1. Tidak memberatkan (عدم التدرج) Artinya: “... Allah menghendaki kemudahan darimu dan tidak menghendaki kesulitan..."(Qs. Al-Baqarah: 185)

Contoh prinsip yang pertama ini antara lain hukum kebolehan berbuka puasa bagi orang yang sedang dalam perjalanan, dan hukum boleh melaksanakan shalat sesuai kemampuan.

2. Menyedikitkan beban

"janganlah kamu bertanya tentang sesuatu yang jika dia diterangkan kepadamu akan menyusahkan kamu”(Qs. al-Maidah ayat 102)

Contoh dari prinsip kedua ini adalah kewajiban haji hanya satu kali seumur hidup bagi yang mampu.

3. Berangsur-angsur

Salah satu keutamaan hukum Islam adalah cara penetapannya yang tidak sekaligus, tetapi secara berangsur-angsur dan bertahap, sehingga tidak memberatkan dan lebih memberikan kelonggaran. Karena al-Qur'an sangat memperhatikan proses

\footnotetext{
${ }^{3}$ Drs. Muin Umar, Dkk., Ushul Fiqh I, Jakarta: Departemen Agama RI, 1986, hlm. 70

${ }^{4}$ Ibid, hlm.21

${ }^{5}$ Drs. Sapiudin Shidiq, M.A, Ushul Fiqh, Jakarta: Kencana Predana Media Group, cet. ke-1 2011, hlm. 49-52
} 


\section{Jurnal Asy-Syukriyyah}

perubahan sosial budaya yang berkembang di masyarakat. Contohnya dalam tahapan pengharaman khamr. ${ }^{6}$

\section{Implementasi Pendidikan Islam Dan Nilai-Nilai Al-Qur'an Dalam Pendidikan}

\section{Karakter Usia Remaja}

Pendidikan Agama merupakan proses pendidikan dan memberikan pengetahuan, membentuk kepribadian, sikap serta keterampilan para remaja dalam mengamalkan norma, nilai, serta ajaran agamanya, selain itu bahwa pendidikan agama Islam ini mengharapkan orang yang sudah mengetahui tentang ajarannya dan dapat memperaktikanya serta mengamalkanya didalam kehidupan sehari-hari karena ajaran didalam agama Islam merupakan ajaran yang baik untuk seluruh manusia. ${ }^{7}$

Peran agama bagi kehidupan remaja yang berkaitan dengan nilai sosial dan budaya ternyata mengalami proses yang begitu panjang kesadaran kualitas remaja sangat dipengaruhi oleh pendidikan dan pengalaman. Keagamaan yang diterimanya sejak kecil terutama dari lingkungan keluarga masa remaja awal (15 - 16 tahun)

Peranan pendidikan agama sangatlah penting bagi kehidupan remaja masa kini, karena pada hakikatnya pendidikan agama adalah suatu pendorong utama, untuk terbentuknya moral remaja yang berakhlak baik. Remaja yang berpendidikan, terutama dalam pendidikan agama akan berbeda dengan remaja yang tak berpendidikan sama sekali. Remaja terdidik adalah remaja yang selalu berpikir pada setiap apa yang akan dilakukannya dan selalu merendahkan diri dari apa yang dimiliki, seperti dalam pribahasa Indonesia "padi semakin berisi semakin merunduk. ${ }^{8}$ " Beda halnya dengan orang yang tak terdidik sama sekali mereka akan selalu bertindak tanpa memikirkan apa yang akan terjadi selanjutnya.

Pendidikan agama akan berkaitan erat dengan pendidikan akidah. Berbicara tentang akidah, yang berkaitan tentang tatakrama, adab dan sebagainya. Sangatlah diperlukan

\footnotetext{
${ }^{6}$ Lihat Q.S. al-Baqarah: 219, Q.S. an-Nisaa: 43, Q.S. al-Maidah: 90

${ }^{7}$ www.academia edu. Com sabtu,8 oktober 2016 pm.11.20

${ }^{8}$ Kata_kata bijak senin 7 november 2016 pm : 11:08
} 
untuk pergaulan remaja pada saat ini, yang semakin menyimpang dan jauh dari moral yang sebelumnya. Maka dengan adanya pendidikan agama sangatlah berpengaruh terhadap moral-moral yang terjadi pada remaja saat ini, sebab pendidikan agama sangat menjunjung tinggi nilai akhlak. Jikalau remaja sudah tidak memiliki akhlak maka hancurlah moralmoral generasi bangsa. Maka dengan adanya pembelajaran akhlak terhadap anak mulai usia dini sangatlah dibutuhkan seperti mencontoh suri tauladan yang baik seperti yang dicerminkan dalam kehidupan Rasulullah SAW. Sebagaimana yang sudah tertera dalam Al-Quran. "sungguh telah ada pada diri seorang rasul suri tauladan yang baik" maka dengan sehubungan terhadap moral remaja kita semua perlu mengkaji akhlak dan etikaetika dalam pergaulan remaja.

\section{Definisi Pendidikan}

Pendidikan merupakan upaya sadar dan terencana yang dilakukan oleh guru untuk mengembangkan potensi secara optimal mencangkup jasmani dan rohani sehingga melalui pendidikan seseorang dapat mengoptimalkan pertumbuhan fisiknya agar memiliki kesiapan untuk melakukan tugas-tugas arah dan tujuan pendidikan. Mengembangkan kemampuan dan membentuk karakter serta peradaban bangsa dan martabat dalam rangka mencerdaskan kehidupan bangsa.

Pendidikan adalah suatu proses yang didesain untuk memindahkan atau menularkan pengetahuan dan keahlian dan kecakapan serta kemampuan pemindahan dan penularan itu berlangsung terus menerus dari suatu generasi kepada generasi lainya.

\section{Pendidikan Menurut Pandangan Islam}

Pada umumnya berbicara tentang pendidikan menurut pandangan Islam, sebagian besar ditekankan pada aspek keagamaan (spiritual) tetapi pada saat bersamaan pendidikan tidak mengabaikan pelajaran-pelajaran dan ilmu pengetahuan sosial, kelebihan dari sistem pendidikan Islam telah mendapatkan atau mengumpulkan pemikiran dari para ulamaulama dan sistem pendidikan formal dan keagamaan dengan mengajarkan pendidikan kesenian untuk kesenjangan hidupnya di masa depan. 


\section{Jurnal Asy-Syukriyyah}

Pendidikan tercangkup dari segala aspek jagat raya ini, bukan hanya terbatas pada manusia semata, yakni dengan menempatkan Allah SWT. Sebagai pendidik yang maha agung, secara garis besar konsep pendidikan dalam pedoman Islam dalam mempertemukan pengaruh dasar dan pengaruh pendidikan diharapkan akan menjadi satu kesatuan yang terpadu kearah pembentukan akhlak yang sempurna. ${ }^{9}$

Ada beberapa menurut para ahli yaitu di antaranya :

1. Menurut M.J. Langeveld yaitu pendidikan merupakan upaya manusia dewasa membimbing manusia yang belum dewasa, kepada kedewasaan dan merupakan usaha menolong anak untuk melaksanakan tugas hidupnya agar bisa mandiri.

2. Menurut John Dewey (1978) Pendidikan adalah segala sesuatu bersamaan dengan pertumbuhan pendidikan sendiri tidak punya tujuan akhir dibalik dirinya. ${ }^{10}$

\section{Definisi Moral}

Moral adalah perbuatan, tingkah laku atau ucapan seseorang dalam berinteraksi dengan manusia. Apabila yang dilakukan seseorang itu sesuai dengan nilai rasa yang berlaku dimasyarakat tersebut dan dapat diterima serta menyenangkan lingkungan masyarakat. Maka orang itu dinilai mempunyai moral yang baik begitu pula sebaliknya, moral adalah produk dari budaya dan agama.

Moral merupakan kondisi pikiran, perasaan, ucapan, dan perilaku manusia yang terkait dengan nilai-nilai baik dan buruk.

Zaman sekarang mempunyai nilai implisit karena banyak orang yang mempunyai moral atau amoral itu dari sudut pandang yang sempit. Moral itu sifat dasar yang diajarkan sekolah-sekolah dan manusia harus mempunyai moral jika ia ingin dihormati. Oleh karena itu, moral adalah nilai keabsolutan dalam kehidupan bermasyarakat secara utuh. Penilaian terhadap moral diukur dari kebudayaan masyarakat setempat. ${ }^{11}$

\footnotetext{
${ }^{9}$ Dj fajar siddik konsep dasar ilmu pendidikan islam (bandung.lita putra media).2016

${ }^{10}$ www.7troprangking.com/2013/02/07

${ }^{11}$ www.taufal serve 612/2015/ landasan teori
} 


\section{Jurnal Asy-Syukriyyah}

Moral menurut para ahli Islam yaitu:

1. Menurut Imam Soekardi ; Moral adalah kebaikan bahwa seseorang pria dengan langkah-langkah yang diadopsi oleh aksi bersama.

2. Menurut Zainuddin Saifullah Nainggolan ; Moral adalah terdiri dari spiritual untuk melakukan serangkaian standar yang mengatur perilaku orang dan masyarakat. ${ }^{12}$

\section{Peran Pendidikan Agama terhadap Moral Remaja}

Masalah pendidikan merupakan masalah universal yang menyangkut pada semua elemen dalam kehidupan berbangsa dan bernegara. Karena pendidikan sebenarnya merupakan kebutuhan pokok dalam melangsungkan dan mempertahankan kehidupan dalam kehidupan manusia. Pendidikan merupakan salah satu aspek penting dalam membentuk generasi yang akan datang. Dengan demikian pendidikan diharapkan dapat menghasilkan manusia berkualitas, bertanggung jawab dan mampu mengantisipasi masa depan.

Pendidikan dalam makna yang luas senantiasa menstimulir yang menyertai perubahan-perubahan dan perkembangan umat manusia. Selain itu, upaya pendidikan senantiasa mengantar, membimbing, perubahan dan perkembangan hidup serta kehidupan umat manusia.

Dilihat dari konsep dasar penciptaannya, manusia merupakan makhluk tuhan yang diberikan amanah sebagai khalifah dimuka bumi. Hal ini tersirat dalam firman Allah Swt yaitu Q.S.Al-Baqarah Ayat 30 :

Artinya : ingatlah ketika Tuhanmu berfirman kepada Para Malaikat: "Sesungguhnya aku hendak menjadikan seorang khalifah di muka bumi." mereka berkata: "Mengapa Engkau hendak menjadikan (khalifah) di bumi itu orang yang akan membuat kerusakan padanya dan menumpahkan darah, Padahal Kami Senantiasa bertasbih dengan memuji Engkau dan mensucikan Engkau?" Tuhan berfirman: "Sesungguhnya aku mengetahui apa yang tidak kamu ketahui."

\footnotetext{
${ }^{12}$ www.pengertian ahli.com id

${ }^{13}$ Depag Al-Qur'an \& terjemah minggu 30 oktober 2016 09:00 wib
} 


\section{Jurnal Asy-Syukriyyah}

Dari ayat di atas dapat disimpulkan bahwa pada hakikatnya, tugas yang dilemban oleh umat manusia sangat berat, dengan kata lain yaitu : sebagai khalifah, yakni khalifah seluruh umat. Oleh sebab itu, merupakan sebuah tantangan yang menuntut untuk lebih berkembangnya pendidikan Islam, terutama dalam upaya meningkatkan dan mengembangkan kualitas sumber daya manusia yang sekarang sedang gencar-gencarnya dikumandangkan.

Pendidikan agama dalam sistem pendidikan nasional tampaknya terdapat konsistensi dan keterkaitan langsung antara rumusan fungsi pendidikan agama dengan tujuan pendidikan nasional yang tertuang pada pasal 3 UUD RI nomor 20 tahun 2003 yaitu: pendidikan nasional berfungsi mengembangkan kemampuan dan membentuk watak serta peradaban bangsa yang bermartabat dalam rangka mencerdaskan kehidupan bangsa, yang bertujuan untuk perkembangan potensi peserta didik agar menjadi manusia yang beriman dan bertakwa kepada Allah Swt, berakhlak mulia serta berilmu, cakap, kreatif, mandiri dan menjadi warga negara demokrasi serta bertanggung jawab. ${ }^{14}$

Dalam upaya membentuk manusia Indonesia yang beriman dan bertakwa maka pendidikan agama memiliki peranan yang sangat penting untuk itulah maka pendidikan agama wajib diberikan kepada semua satuan, jenjang dan jenis pendidikan baik melalui jalur dalam sekolah maupun jalur luar sekolah.

Agama Islam adalah agama universal yang mengajarkan kepada umat manusia yang mengenai berbagai aspek kehidupan baik duniawi, maupun akhirat. Salah satu ajaran Islam tersebut adalah mewajibkan kepada umat Islam, iman, percaya, sumbernya yang asasi ialah al-Qur'an. Aqidah adalah masalah fundamental Islam yang menjadi tolak permulaan muslim. Sebaliknya, tegaknya aktivitas keIslaman dalam hidup dan kehidupan seseorang itulah yang dapat menerangkan bahwa orang itu memiliki akidah atau menunjukan kualitas iman yang di miliki. Manusia hidup atas dasar kepercayaan tinggi rendahnya nilai kepercayaan memberi corak kepada kehidupan atau dengan kata lain tinggi

\footnotetext{
${ }^{14} \mathrm{http} /$ /google weblight com .sabtu 12 november 2016 pm 11:35
} 
rendahnya kehidupan manusia tergantung kepada kepercayaan yang dimilikinya. Sebab itulah kehidupan pertama dalam Islam di mulai dengan iman sebagaimana firman Allah Swt. Dalam Q.S.Luqman ayat : 13

Artinya : Dan (ingatlah) ketika Luqman berkata kepada anaknya, di waktu ia memberi pelajaran kepadanya: "Hai anakku, janganlah kamu mempersekutukan Allah, Sesungguhnya mempersekutukan (Allah) adalah benar-benar kezaliman yang besar".(13) ${ }^{15}$

Dari firman tersebut dapat kita simpulkan dan dapat kita pahami bahwa penilaian, nilai-nilai akidah kepada anak hendaknya dilakukan sedini mungkin secara konsista maupun berkesinambungan. Hal ini bertujuan untuk memperkokoh keimanan yang telah ia bawa sejak lahir ke dunia ini.

Aspek kedua setelah akidah yaitu aspek ibadah. keduanya berhubungan erat dan dapat di simpulkan bahwa hakikat ibadah adalah menumbuhkan kesadaran pada diri manusia. Bahwa ia sebagai insan di ciptakan Allah swt khusus untuk mengabdi kepadanya. Di dalam al-quran Allah SWT berfirman:

Artinya: "Dan aku tidak menciptakan jin dan manusia melainkan supaya mereka mengabdi kepada-Ku”. (56) $)^{116}$

Dengan kata lain ibadah dapat menciptakan insan yang berakhlakul karimah. Selain dari pada itu tidak kalah pentingnya dalam menentukan kepribadian seseorang muslim adalah aspek akhlak. Menurut Rozak pendidikan akhlak adalah faktor penting dalam membina suatu umat atau membangun suatu bangsa. Jika manusia pelaksanaan tidak memiliki akhlak, niscaya segalanya akan berantakan dan sia-sia, akibat penyelewengan dan korupsi, yang diperlukan pengembangan ialah keikhlasan, kejujuran, jiwa kemanusiaan, yang tinggi dan kedisplinan.

Dari segi aspek akidah, ibadah, dan akhlak ketiganya saling berhubungan laksana bejana, mengatur kehidupan manusia dalam semua aspek baik secara individual maupun

\footnotetext{
${ }^{15}$ Depag al quran\& terjermah minggu 30 oktober 2016 09:32 wib Depag Al Qur"an dan Terjemah

${ }^{16}$ Depag al quran\& terjermah minggu 30 oktober 2016 09:32 wib Depag Al Qur"an dan Terjema
} 


\section{Jurnal Asy-Syukriyyah}

secara sosial, ketiganya merupakan ilmu ilahi yang bersifat abadi yang menjadi sumber insani yang tidak ada dalam semua displin ilmu.

Menurut Gunarsa remaja merupakan masa pelatihan antara massa anak-anak dan massa dewasa yakni antara umur 12-21 tahun. Remaja yang merupakan masa dimana masa individu dalam proses pertumbuhan terutama fisik, telah mencapai kematangan, pada masa lain perubahan-perubahan jasmaniah yang berkaitan dengan kematangan jenis kelamin, terlihat dari perkembangan psikososial yang berhubungan dengan fungsi seseorang dalam lingkungan sosial, yakni kebanyakan para remaja, melepaskan diri dari ketergantungan dengan orang tua, pembentukan rencana hidup dan pembentukan sistem nilai-nilai.

Masa remaja merupakan operasi mental tingkat tinggi, anak-anak remaja sudah dapat berhubungan dengan peristiwa-peristiwa hipotesis atau abstrak, tidak halnya dengan objek-objek kongkrit, remaja juga dapat berpikir abstrak dan dapat memecahkan masalah melalui pengujian alternatif yang ada.

Bagi remaja sangat diperlukan adanya pemahaman, pendalaman, serta ketaatan terhadap ajaran-ajaran agama yang dianggap masing-masing dari kenyataan sehari-hari sudah banyak anak remaja yang menunjukan bahwa sebagian besar anak-anak remaja yang melakukan kejahatan, penyimpangan, dan lain-lain. Yang di akibatkan karena kurangnya mempelajari dan memahami agama, bahkan mungkin saja lalai dalam menunaikan ibadahibadah serta perintah-perintah agama.

Ada dalam sebuah hadist nabi yang menyebutkan bahwa manusia dilahirkan dalam keadaan fitrah, namun kedua orang tuanyalah yang akan memberikan agama kepada mereka yang dilahirkannya itu. ${ }^{17}$

Dalam upaya membentuk manusia yang beriman dan bertaqwa pendidikan agama memiliki peranan yang sangat penting bagi anak-anak penerus bangsa selanjutnya, maka dari itu pendidikan agama wajib diberikan kepada semua satuan, jenjang dan jenis pendidikan baik melalui jalur sekolah maupun luar sekolah.

${ }^{17}$ www.kompasania com. Id senin 07 november $2016 \mathrm{pm} / / 11: 23$ 


\section{Jurnal Asy-Syukriyyah}

Agama Islam adalah agama yang universal yang mengajarkan kepada umat manusia agar dapat mengenal berbagai aspek kehidupan baik di duniawi maupun di akhirat. Salah satu diantara ajaran Islam tersebut adalah mewajibkan kepada umat Islam untuk mencari ilmu, menuntut ilmu dan melaksanakan pendidikan, karena menurut ajaran Islam pendidikan juga merupakan kebutuhan hidup manusia yang mutlak harus dipenuhi agar dapat mencapai kesejahteraan dan kebahagiaan dunia dan di akhirat.

Dengan pendidikan itu, manusia akan mendapatkan berbagai macam ilmu pengetahuan untuk bekal dalam kehidupannya. Tentang bagaimana jiwa dan kepribadiannya seseorang anak serta bagaimana selanjutnya, semua tergantung bagaimana cara kita memberikan pendidikan utamanya pendidikan agama sebagai modal kepribadiannya.

Menurut Zuharini menerangkan bahwa fitrah beragama pada manusia telah dibawa sejak lahirnya, maka fitrah tersebut akan berkembang dengan adanya pendidikan. Karena adanya fitrah beragama itu maka manusia disebut homodinivas (makhluk ketuhanan) atau juga disebut homo religious (makhluk yang beragama), karena dengan adanya agama manusia akan mendapatkan ketentraman lahir dan batin.

Manusia pada hakikatnya mempunyai kebebasan dan menentukan perjalanan hidupnya masing-masing. Dalam ajaran Islam memang terdapat kebebasaan yang seluasluasnya bagi manusia untuk melakukan sesuai dengan kehendaknya masing-masing baik dalam bidang ekonomi, politik, maupun dalam bidang sosial.

Kebebasan yang diberikan Allah Swt. Kepada umat Islam bukan berarti lepas sama sekali dari norma-norma sosial melainkan kebebasan yang dimiliki itu, yang bertanggung jawab dengan apa yang telah dilakukan dan telah menjadi keputusanya itu.Agama dan norma-norma sosial menjadi suatu tolak ukur dalam semua kehidupan karena sudah tertulis oleh pola kehidupan yang telah terjadi pada saat zaman sekarang ini. Hal ini dikarenakan minimnya organisasi keagamaan, kesadaran orang tua terhadap pentingnya pendidikan agama dan minimnya perhatian masyarakat akan tingkah laku para remaja saat ini. 


\section{Jurnal Asy-Syukriyyah}

\section{Minat Remaja terhadap Pendidikan Agama}

Dengan berkembangnya zaman dari masa kemasa banyak perubahan-perubahan pada remaja-remaja zaman sekarang ini. Seperti yang kita ketahui bahwa para remaja sekarang hanya beberapa persen yang mempunyai minat untuk mempelajari dan mendalami ilmu agama tersebut. Karena sebagian orang lainnya lebih mementingkan pendidikan yang mereka anggap itu bagus, bisa meninggikan derajatnya atau mengharumkan namanya karena dianggap mudah mendapatkan kemewahan duniawi. Akibat yang mereka tidak sadari bahwa mereka yang menyepelekan pendidikan agama tersebut akan jauh dari Allah Swt. secara tidak sengaja maupun disengaja mereka akan berubah dan terpengaruh oleh budaya luar dan melupakan pendidikan agama yang memang harus dipelajari tetapi sekarang hanya sebagian persen saja yang mempelajari dan mendalami pendidikan agama. ${ }^{18}$

Minat remaja menurut Hurlock (2004), pada masa terjadi perubahan minat seiring dengan pertumbuhan dan perkembangannya. Ada 7 minat utama pada masa remaja yaitu :

1. Minat rekreasi

2. Minat sosial

3. Minat pribadi

4. Minat pendidikan

5. Minat pekerjaan

6. Minat kepada agama

7. Minat kepada simbol dan status

\section{Pentingnya Pendidikan Agama terhadap Moral Remaja}

Zaman sekarang agama telah menjadi nomor yang kesekian untuk para remaja karena banyak para remaja zaman sekarang yang melalaikan kewajibanya pada Allah, mereka mementingkan yang mereka inginkan. Misalnya, ketika adzan telah dikumandangkan seharusnya sebagian orang Islam harus segera menyegerakan solat, ini

${ }^{18}$ www.m. kompasania com minggu 20 november 2016 pm//9.26 


\section{Jurnal Asy-Syukriyyah}

disebabkan karena remaja zaman sekarang kurang memahami akan pentingnya pendidikan agama.

Agama sangatlah penting untuk kehidupan dan menjadi pedoman agama Islam, karena pendidikan agama bisa membuat kita bisa lebih bisa menjalankan perintah dan menjauhi larangan, pendidikan agama berisi tentang aturan-aturan kehidupan, pengendalian diri, dari perbuatan keji dan munkar. ${ }^{19}$

Kini kita bisa melihat dan mengajari bahwa kini zaman semakin rusak karena kurangnya pemahaman akan agama, seperti akibatnya menurunya moral remaja banyaknya pemerkosaan, banyaknya beredar video porno, pencurian, korupsi dan lain-lain. Dari berbagai contoh tersebut kita dapat melihat bahwasanya remaja sekarang akhlaknya telah rusak karena kurangnya pemahaman pendidikan agama.

Menurut Dahlan (2016 :109) mengatakan bahwa “ akhlak Islam dapat diartikan sebagai akhlak yang bersumber pada ajaran Islam, dimana penentu baik buruknya menggunakan tolak ukur ketentuan Allah yang bersumber kepada wahyu Allah. " maka dari itu kita harus berpegang teguh mempelajari dan mengamalkan apa yang telah di wahyukan oleh Allah yaitu kita kitab suci Al-Quran ${ }^{20}$

Akhlak yang baik dapat dibentuk dari dalam dan setiap individu atau perorangan karena Allah memerintahkan hambanya untuk mempunyai akhlak yang mulia (akhlakul karimah) dan menjauhi akhlak yang buruk atau tercela. Jadi pendidikan agama itu sangat penting bagi kehiduapan baik anak-anak, remaja, dewasa, tua, bahkan sampai akhir hayat atau ajal menjemput. Maka kita wajib mencari mempelajari dan menambahkan itu tentang agama (mendalami ilmu agama) karena kita sebagai remaja akan menjadi penerus bangsa.

\footnotetext{
${ }^{19} \mathrm{http} . / /$ google weblight com senin 07 november $2016 \mathrm{pm} . / / 10.25$

${ }^{20}$ www.google co.id. 10 november 2016 pm.// 08.56
} 


\section{Jurnal Asy-Syukriyyah}

\section{Kesimpulan}

Pendidikan Nonformal berkaitan erat pada pendidikan agama. Pendidikan agama merupakan proses pendidikan dan memberikan pengetahuan membentuk kepribadian sikap serta keterampilan para remaja dalam mengamalkan norma, nilai, serta ajaran agamanya. Peranan pendidikan agama sangatlah penting bagi kehidupan remaja masa kini.

Untuk mencetak remaja-remaja yang berpendidikan serta memiliki moral yang berbudi pekerti luhur, maka hendaklah para orang tua menanamkan pendidikan agama kepada anak usia dini. Agar mereka mengetahui kepada tuhannya serta rasulnya, dan mereka juga dapat mengetahui bahwasanya agama memiliki suatu larangan terhadap setiap semua perilaku yang tercela, karena banyak sekali remaja yang sukses tapi sangat disayangkan tidak memiliki sama sekali pondasi agama dalam diri mereka, maka tidak sedikit dari mereka yang mengalami kegagalan dari kesuksesannya dikarenakan kebanyakan dari mereka terjerumus kedalam lembah yang nista. 


\section{DAFTAR PUSTAKA}

Ahmad Mubarok. 2009. “Arti Imam.” http://mubarok-institute.blogspot.com. Diakses tanggal 31 Maret 2012.

Al-Bukhariy, 1981, Abu Abdillah Muhammad bin Ismail bin Ibrahim bin alMughirah, Shahih al-Bukhâriy, Beirut : Dâr al-Fikr.

Hendratno. 2012. "Mengamalkan al-Qur'an Mulai dari Mana?." http://www.dakwatuna.com diakses tanggal 15 Maret 2012

Ibnu Majah, Abi Abdullah Muhammad bin Yazid al-Qazwiniy, t.th. Sunan Ibnu Majah, : Dâr al-Fikr.

Jawas, Yazid Abdul Kadir, 1993, Kedudukan as-Sunnah dalam Syarat Islam, Jakarta : Pustaka al-Kautsar.

Al-Khatib, Muhammad Ajjaj, 1989, Ushûl al-Hadîs; 'Ulûmuhu wa Musthalahuhu, Beirut : Dâr al-Fikr.

Muchtar, Heri Jauhari, Fikih Pendidikan, Surabaya : PT. Remaja Rosda Karya.

Al-Naisaburiy, Abu al-Hasan Muslim bin Hajjaj al-Qushairiy, t.th. Shahih Muslim, Beirut : Dâr al-Ihya' al-Turâts al-'Arabi.

Al-Qattan, Manna' Khalil, t.th. Mabâhits fiy 'Ulum al-Qur'an, Beirut : Muassasah alRisâlah.

Al-Sajistaniy, Abu Daud Sulaiman bin al-'Asy'ats, t.th. Sunan Abu Daud, Jakarta: Maktabah Dahlan.

Shihab, Muhammad Quraish, Wawasan al-Qur'an; Tafsir Maudhu'i atas Pelbagai Persoalan Umat, 1997, Bandung : Mizan.

------, Tafsir al-Mishbah; Pesan, Kesan dan Keserasian al-Qur'an, 2002, Jakarta : Lentera Hati.

Al-Turmudziy, Muhammad bin Musa bin Tsaurah, t.th. Sunan al-Turmudziy, Beirut: Dâr al-Fikr.

Wahid, Ramli Abdul, 2003, Studi Ilmu Hadis, Medan: PP2-IK. 


\section{Jurnal Asy-Syukriyyah}

Zamraliy, Fawwaz Ahmad, al-Quwl al-Munif fi Hukm al-'Amal bi al-Hadits al-Dha'if, 1995, Beirut : Dar Ibn Hazm.

Mahfuzh, Jamaluddin, M. 2009. Psikologi Anak dan Remaja Muslim. Jakarta : Pustaka Al - Kautsar.

Depag \& al-Qur'an Terjemah, minggu 24 oktober 201609 : 00 WIB

http// pustaka, com, id, /pustaka/ online, kamis 28 oktober 2016 pm : $02: 30$

http// google weblight, com, jumat 29 oktober 20162016 pm : 01 :00

Panjaitan, Putra, Ade. 2016 Kopelasi \& Kebudayaan Pendidikan, Jakarta IKPI. Dki Jakarta

Siddik Djfajar. 2006 Konsep Dasar Ilmu Pendidikan Islam. Bandung Lita Putra Media. www. Taufal Serve 612/2015/ Landasan Teori com. Senin, 10 oktober pm: 10: 57 www. Informasiahli. Com. Jumat, 14 oktober 2016 pm: 10:57

www. Academia, edu, com, sabtu 8 oktober 2016 pm : 11:23

www. Pengertian ahli. Com. Id. Sabtu 05 november pm : 11:20

www. Troprangking, com / 2013/ 02 /07/ minggu 06 november 2016 pm : 11 :00

www. Google com, id, selasa 22 november 2016 pm : 12: 30 